Юрій ПОЛУЛЯЩЕНКО, orcid.org/0000-0002-4149-5500 кандидат педагогічних наук, професор кафедри олімпійського і професійного спорту Луганського начіонального університету імені Тараса Шевченка (Старобільськ, Луганська область, Україна) spartak_lg@ukr.net

\title{
ПРИНЦИПИ ПРОФЕСІЙНОЇ ПІДГОТОВКИ МАЙБУТНІХ ВЧИТЕЛІВ ФІЗИЧНОӤ КУЛЬТУРИ ДО ФОРМУВАННЯ ПАТРІОТИЧНИХ ЦІННОСТЕЙ УЧНІВСЬКОЇ МОЛОДІ
}

\begin{abstract}
Стаття присвячена проблемі професійної готовності майбутніх вчителів фізичної культури до виховання патріотичних цінностей учнівської молоді. Основна увага зосереджена на характеристиці запропонованих автором принципів, які мають лягти в основу розробки педагогічної системи професійної підготовки майбутніх вчителів фізичної культури до формування патріотичних изіностей учнівської молоді: принцип відповідності проиесу професійної підготовки майбутніх вчителів фізичної культури реаліям сьогодення; принцип прогнозування та превентивності; принцип громадянської свідомості; принцип урахування регіональних особливостей $i$ ментальності студентів; принциип ичілеспрямованості навчально-виховного процесу на формування професійної готовності майбутніх вчителів фізичної культури до формування патріотичних цінностей учнівської молоді.

У статті наводяться концептуальні положення побудови педагогічної системи професійної підготовки майбутніх вчителів фізичної культури до формування патріотичних иінностей учнівської молоді. Перше концептуальне положення передбачає, щзо теоретико-методичні засади професійної підготовки майбутніх вчителів фізичної культури до формування патріотичних цінностей учнівської молоді розглядаються автором з позиції системного підходу. Друге концептуальне положення грунтується на розумінні того, щзо навчальна та позанавчальна діяльність із фізичної культури має потужний потенціал у формуванні патріотичних иінностей учнівської молоді.

Третє концептуальне положення полягає в тому, щзо процес професійної підготовки майбутніх вчителів фізичної культури до формування патріотичних иінностей учнівської молоді має відбуватися з урахуванням зорієнтованості навчального прочесу в контексті набуття учнями ключових компетентностей, передбачених основами стандарту «Нова українська школа». Четвертим концептуальним положенням передбачається, щзо підготовка майбутніх вчителів фізичної культури до формування патріотичних иінностей учнівської молоді має здійснюватися поетапно протягом усього періоду навчання у $3 В О$
\end{abstract}

Ключові слова: професійна підготовка, принципи, майбутні вчителі фізичної культури, патріотичні цінності.

Yurii POLULIASHCHENKO, orcid.org/0000-0002-4149-5500

Candidate of Pedagogical Sciences,

Professor at the Department of Olympic and Professional Sports Luhansk Taras Shevchenko National University (Starobilsk, Luhansk region, Ukraine) spartak_lg@ukr.net

\section{PRINCIPLES OF PROFESSIONAL TRAINING OF FUTURE TEACHERS OF PHYSICAL CULTURE FOR THE FORMATION OF PATRIOTIC VALUES OF STUDENT YOUTH}

The article is devoted to the problem of professional readiness of future physical education teachers to educate patriotic values of student youth. The main attention is focused on the characteristics of the principles proposed by the author, which should form the basis for the development of a pedagogical system of professional training of future physical education teachers for the formation of patriotic values of student youth, in particular: the principle of conformity of the process of professional training of future teachers of physical culture to the realities of today; the principle of forecasting and prevention; the principle of civic consciousness; the principle of taking into account regional features and mentality of students; the principle of purposefulness of the educational process on the formation of professional readiness of future physical education teachers for the formation of patriotic values of student youth.

Conceptual provisions of construction of pedagogical system of professional training of future teachers of physical culture to formation of patriotic values of student's youth are resulted, in particular, respectively, the first conceptual position provides that the theoretical and methodological principles of professional training of future teachers of physical 
education to the formation of patriotic values of student youth are considered by the author from the standpoint of a systematic approach. The second conceptual position is based on the understanding that educational and extracurricular activities in physical culture have a powerful potential in the formation of patriotic values of student youth.

The third conceptual position is that in the process of professional training of future physical education teachers for the formation of patriotic values of student youth should take into account the orientation of the educational process in the context of the acquisition by students of key competencies provided by the basics of the Standard "New Ukrainian school". The fourth conceptual provision stipulates that the preparation of future physical education teachers for the formation of patriotic values of student youth should be carried out in stages throughout the period of study in a higher education institution.

Key words: professional training, principles, future teachers of physical culture, patriotic values.

Постановка проблеми. На сучасному етапі розвитку країни проблема формування патріотичних цінностей учнівської молоді набуває особливої актуальності, що насамперед пов'язано із агресією з боку РФ проти України. Певна частина мешканців Донбасу була зомбована шляхом ведення інформаційної війни проти нашої країни. Неочікуваність багатьма українцями підступного нападу, а також віра в те, що росіяни - братній нам народ певним чином вплинула на довірливість окремих громадян медіа-ресурсам РФ. Тому нині особливо важливо напрацювати теоретичні та методичні засади професійної підготовки майбутніх вчителів, зокрема вчителів фізичної культури, оскільки саме сфера фізичної культури і спорту має надзвичайно потужний потенціал у контексті формування патріотичних цінностей учнівської молоді.

Аналіз досліджень. Для цієї статті особливе значення мали наукові напрацювання вітчизняних вчених I. Бех [1; 2], О. Карамана [3], В. Курило [3], Р. Проця [4], С. Савченко [3], М. Чепіль [5], Н. Череповської [6].

Мета статті - висвітлити принципи і концептуальні положення як важливий методологічний складник процесу професійної підготовки майбутніх вчителів фізичної культури до формування патріотичних цінностей учнівської молоді.

Виклад основного матеріалу. Аналіз праць зазначених вище дослідників та інших наукових робіт дозволив запропонувати принципи, які мають лягти в основу розробки педагогічної системи професійної підготовки майбутніх вчителів фізичної культури до формування патріотичних цінностей учнівської молоді.

Принцип відповідності процесу професійної підготовки майбутніх вчителів фізичної культури реаліям сьогодення. Цим принципом передбачається побудова процесу професійної підготовки майбутніх вчителів фізичної культури (змісту, технологій навчання) з урахуванням вимог часу, а також реальних обставин, 3 якими зіштовхнулася країна за останні шість років. Йдеться про гібридну війну з боку Російської Федерації проти України.
Тривалий час традиційний зміст професійної підготовки майбутніх вчителів фізичної культури був спрямований на оволодіння студентами вміннями щодо організації рухової активності. Останні роки показали, що формування патріотичних цінностей учнівської молоді має відбуватися 3 використанням усього потенціалу різних соціальних інституцій, в тому числі й потенціалу фізичної культури; вони сприяли усвідомленню значущості підвищення рівня сформованості патріотичних цінностей учнівської молоді (в тому числі й у контексті протидії інформаційній війні проти України з боку РФ), що спонукало до розуміння важливості фізичної культури та іiї можливостей як у контексті формування патріотичних цінностей учнівської молоді, так і в контексті військово-патріотичного виховання, яке має відбуватися, базуючись на традиціях українського народу, надбанні запорізьких козаків у зазначеному вище контексті.

Принцип прогнозування та превентивності. Відповідно до цього принципу передбачається урахування наявних тенденцій щодо удосконалення процесу підготовки майбутніх вчителів фізичної культури, спираючись на реформування системи освіти та нові вимоги до вчителя фізичної культури. Наявні зміни у змісті освіти вимагають по новому поглянути на процес організації фізичної культури в закладах середньої освіти.

Відповідно до основ стандарту «Нова українська школа» в межах фізкультурної освіти учнів передбачається оволодіння останніми ключовими життєвими компетентностями: спілкування рідною / державною мовою; спілкування іноземними мовами; математична компетентність; компетентності уприродничих науках і технологіях; інформаційноцифрова компетентність; уміння вчитися протягом життя; соціальна компетентність для здоров'я i добробуту; компетентності для демократичного громадянства; ініціативність і підприємливість, обізнаність і самовираження у сфері фізичної культури.

Цим принципом передбачається не лише зорієнтованість процесу підготовки майбутніх вчителів фізичної культури на здобуття остан- 
німи професійної готовності щодо формування в учнів відповідних компетентностей, але й спрямованість на формування патріотичних цінностей учнівської молоді. Принцип спрямований на урахування в процесі професійної підготовки майбутніх вчителів фізичної культури подальших підступних дій з боку Російської Федерації в контексті «зомбування» частини населення взагалі та самих студентів зокрема. Відповідно до цього принципу при побудові змістовного складника процесу професійної підготовки майбутніх вчителів фізичної культури має враховуватися досвід протидії інформаційній війні (як одного зі складників гібридної війни), яку веде РФ проти України. Також необхідно враховувати можливість застосування РФ нових методів впливу на свідомість молодих людей.

Принцип громадянської свідомості. Цим принципом передбачається, що процес підготовки майбутніх вчителів фізичної культури має бути спрямований на підвищення відчуття у студентів відповідальності за власну поведінку, яка має відповідати моральним нормам і вияву патріотизму в усіх сферах життя. Насамперед це передбачає спрямованість на виховання свідомих громадян, які люблять власну країну, а також розвиток у них бажання докладати максимум зусиль для розвитку заможної демократичної країни, зорієнтованої на європейські цінності, спроможної розвиватися, відстоювати виключно національні інтереси.

Принцип урахування регіональних особливостей і ментальності студентів передбачає урахування регіональних і ментальних особливостей студентів, які бажають стати майбутніми педагогами (вчителями фізичної культури). Розроблення цього принципу зумовлюється тим, що, як показала реальна практика проведення гібридної війни, в різних регіонах країни студентська молодь по-різному реагувала на агресію РФ. Відомі випадки, коли в окремих регіонах Сходу та Півдня України студенти не сприймали Російську Федерацію як ворога, який веде війну проти України. Також відомі випадки пасивності і навіть відсутності виявів патріотизму 3 боку окремих студентів, що $є$ наслідком впливу інформаційної війни з боку РФ, оскільки на цих територіях проживають багато російськомовних громадян. Натомість у Центрі та на Заході України студенти показали досить високий рівень патріотизму й усвідомлення РФ як ворога України. У зв'язку з цим вказаним принципом передбачено урахування регіональних особливостей як при розробленні змісту дисциплін і спецкурсів, так і при підборі відповідних технологій навчання в контексті підвищення рівня сформованості патріотизму у майбутніх вчителів фізичної культури.

Принцип цілеспрямованості навчальновиховного процесу на формування професійної готовності майбутніх вчителів фізичної культури до формування патріотичних цінностей учнівської молоді. Цим принципом передбачається, що процес професійної підготовки має бути повністю спрямований на набуття студентами під час навчання у ЗВО відповідної спеціальності професійної готовності майбутніх вчителів фізичної культури до формування патріотичних цінностей учнівської молоді, що має досягатися не лише епізодичними заходами у позанавчальному процесі (як це здебільшого відбувається), а шляхом передбачення змістом фахових дисциплін відповідної тематики протягом усього періоду навчання (з першого по восьмий семестри включно). Науково-дослідна робота студентів, а також практика за фахом також мають передбачати обов'язкові завдання в контексті набуття мінімально необхідного досвіду з формування патріотичних цінностей учнівської молоді в процесі фізичної культури (в навчальній і позанавчальній діяльності).

Принцип урахування значущості теоретичного складника фізичної культури у школі в контексті формування патріотичних цінностей учнів. Відповідно до цього принципу процес підготовки майбутніх вчителів фізичної культури має враховувати важливий потенціал теоретичного складника фізичної культури у школі. У зв'язку з цим при вивченні фахових дисциплін мають добиратися такі технології навчання, за допомогою яких студенти набували б необхідних комунікативних вмінь, а також вмінь якісно викладати теоретичний матеріал 3 фізичної культури, застосовуючи інтерактивні методи навчання.

У межах цієї публікації ми зупинимося на розгляді концептуальних положень як важливого методологічного складника процесу професійної підготовки майбутніх вчителів фізичної культури до формування патріотичних цінностей учнівської молоді.

Перше концептуальне положення полягає в тому, що теоретико-методичні засади професійної підготовки майбутніх вчителів фізичної культури до формування патріотичних цінностей учнівської молоді ми розглядаємо з позиції системного підходу, тобто як педагогічну систему, яка передбачає цільовий (мета, завдання), суб'єкт-об'єктний (рівноправна взаємодія учасників процесу), змістовний (розробка відповідного змісту професійної підготовки) та процесуальний (розробка дидак- 
тичного забезпечення процесу підготовки) компоненти, які взаємодіють одне з одним як єдине ціле.

Провідне поняття дослідження «патріотичні цінності учнівської молоді» ми розглядаємо як таке, що характеризується усвідомленням особистістю значущості любові до Батьківщини; бажанням iï захищати та спрямованістю доводити це реальними діями; стійким переконанням у потребі постійно сприяти добробуту власної країни; розумінням безперестанної боротьби за iii теперішне і майбутнє; готовністю дати відсіч будь-якому агресору; впевненістю у потребі бути національно свідомим, порядним, благородним, вірним традиціям козацького роду, відповідальним, шанобливим до своїх співгромадян та поважати інші держави світу.

Друге концептуальне положення грунтується на розумінні того, що навчальна та позанавчальна діяльність із фізичної культури має потужний потенціал у формуванні патріотичних цінностей учнівської молоді. Це вимагає пошуку нових підходів до формування професійної готовності майбутніх вчителів фізичної культури в контексті використання відповідного потенціалу щодо забезпечення якісного процесу виховання патріотичних цінностей молодого покоління.

Трете концептуальне положення полягає в тому, що процес професійної підготовки майбутніх вчителів фізичної культури щодо формування патріотичних цінностей учнівської молоді має відбуватися 3 урахуванням зорієнтованості навчального процесу в контексті набуття учнями ключових компетентностей, передбачених основами стандарту «Нова українська школа».

Ще одне провідне поняття дослідження «професійна готовність майбутніх вчителів фізичної культури до формування патріотичних цінностей учнівської молоді» ми визначаємо як стійку особистісну якість, яка характеризується наявністю відповідних теоретичних знань і практичних умінь (гностичні, проективні, конструктивні, організаційні, комунікативні), а також наявністю у студентів стійкої мотивації до формування патріотичних цінностей учнівської молоді у процесі фізичної культури, високого ступеню психологічної стійкості, переконаності у потребі професійного самовдосконалення та самореалізації.

Четверте концептуальне положення полягає у тому, що підготовка майбутніх вчителів фізичної культури до формування патріотичних цінностей учнівської молоді має здійснюватися поетапно протягом усього періоду навчання у ЗВО. На кожному з етапів професійної підготовки передбачається пошук нових, найбільш оптимальних підходів щодо вдосконалення змісту фахової підготовки та педагогічної практики майбутніх вчителів фізичної культури, застосування інтерактивних технологій навчання, удосконалення процесу навчальної та науководослідної діяльності студентів, здійснення системного моніторингу якості набутих знань, умінь і навичок у зазначеному вище контексті, побудови навчального процесу на основі суб'єктсуб'єктної взаємодії студентів і професорськовикладацького складу в контексті підвищення рівня їхньої професійної готовності (науково-теоретичної, практичної, психологічної) до формування патріотичних цінностей учнівської молоді.

П'ятим конщептуальним положенням передбачається, що майбутній вчитель фізичної культури протягом навчання у ЗВО має оволодіти не лише сукупністю необхідних знань, умінь і мінімального досвіду у сфері формування патріотичних цінностей учнівської молоді (у навчальному та позанавчальному процесах), але й бути патріотом власної країни, володіти стійкою мотивацією щодо формування патріотичних цінностей учнівської молоді, бути психологічно стійкою особистістю, спрямованою на професійне самовдосконалення у сфері формування патріотичних цінностей учнівської молоді протягом всієї майбутньої професійної діяльності.

Висновки. Можна зробити такі висновки:

1. Охарактеризовано принципи, які мають лягти в основу розробки педагогічної системи професійної підготовки майбутніх вчителів фізичної культури до формування патріотичних цінностей учнівської молоді: принцип відповідності процесу професійної підготовки майбутніх вчителів фізичної культури реаліям сьогодення; принцип прогнозування та превентивності; принцип громадянської свідомості; принцип урахування регіональних особливостей і ментальності студентів; принцип цілеспрямованості навчально-виховного процесу на формування професійної готовності майбутніх вчителів фізичної культури до формування патріотичних цінностей учнівської молоді.

2. Аналіз наукових робіт дозволив розробити концепцію побудови педагогічної системи професійної підготовки майбутніх вчителів фізичної культури до формування патріотичних цінностей учнівської молоді. В основу концепції дослідження покладено сукупність теоретичних положень. Перше концептуальне положення передбачає, що теоретико-методичні засади професійної підготовки майбутніх вчителів фізичної культури до формування патріотичних цінностей учнівської молоді ми розглядаємо 3 позиції сис- 
темного підходу. Друге концептуальне положення грунтується на розумінні того, що навчальна та позанавчальна діяльність із фізичної культури має потужний потенціал у формуванні патріотичних цінностей учнівської молоді. Третє концептуальне положення полягає у тому, що процес професійної підготовки майбутніх вчителів фізичної культури до формування патріотичних цінностей учнівської молоді має відбуватися 3 урахуванням зорієнтованості навчального процесу в контексті набуття учнями ключових компетентностей, передбачених основами стандарту «Нова україн- ська школа». Четверте концептуальне положення полягає у тому, що підготовка майбутніх вчителів фізичної культури до формування патріотичних цінностей учнівської молоді має здійснюватися поетапно протягом усього періоду навчання у ЗВО. П'ятим концептуальним положенням передбачається, що майбутній вчитель фізичної культури протягом навчання у ЗВО має оволодіти не лише сукупністю необхідних знань, умінь і мінімального досвіду у сфері формування патріотичних цінностей учнівської молоді, але й бути патріотом своєї країни.

\section{СПИСОК ВИКОРИСТАНИХ ДЖЕРЕЛ}

1. Бех І. Програма українського патріотичного виховання дітей та учнівської молоді. Гірська школа Українських Kapnam. 2015. №№ 12-13. C. 26-37.

2. Бех І. Д. Компонентна модель сходження зростаючої особистості до духовних цінностей. Теоретико-методичні проблеми виховання дітей та учнівської молодi : зб. наук. праць. Інститут проблем виховання НАПН України. Вип. 21. Кн. 1. Київ, 2017. С. 6-21.

3. Курило В. С., Савченко С. В., Караман О. Л. Соціалізація особистості в умовах гібридної війни на сході Украіни : монографія. К. : Талком, 2018. 240 с.

4. Проць Р. О. Етнопедагогічні засади військово-патріотичного виховання молоді засобами фізичної культури і спорту : дис. канд. пед. наук: 13.00.07. Дрогобич. 2015. 227 с.

5. Чепіль М. М. Патріотичне виховання в педагогічній концепції Григорія Ващенка. Педагогічна освіта: теорія і практика. 2015. Вип. $18 . \quad$ С. 116-121.

6. Череповська Н. І. Медіаосвітні ресурси розвитку патріотизму і критичного мислення молоді : навч. посіб. Кропивницький : Імекс-ЛТД, 2017. 156 с.

\section{REFERENCES}

1. Bekh I. Prohrama ukrainskoho patriotychnoho vykhovannia ditei ta uchnivskoi molodi. [Program of Ukrainian patriotic education of children and students]. Hirska shkola Ukrainskykh Karpat-Mountain school of the Ukrainian Carpathians, 2015, № 12-13, p. 26-37 [in Ukrainian].

2. Bekh I. D. Komponentna model skhodzhennia zrostaiuchoi osobystosti do dukhovnykh tsinnostei. [A component model of the ascent of a growing personality to spiritual values]. Teoretyko-metodychni problemy vykhovannia ditei ta uchnivskoi molodi : zb. nauk. prats. 2017, issue 21, Vol. 1, Kyiv, p. 6-21 [in Ukrainian].

3. Kurylo V. S., Savchenko S. V., Karaman O. L. Sotsializatsiia osobystosti v umovakh hibrydnoi viiny na skhodi Ukrainy. [Socialization of the individual in the conditions of a hybrid war in the east of Ukraine]. Monograph. Kyiv : Talcum, 2018, p. 240 [in Ukrainian].

4. Prots R. O. Etnopedahohichni zasady viiskovo-patriotychnoho vykhovannia molodi zasobamy fizychnoi kultury i sportu. [Ethnopedagogical principles of military-patriotic education of youth by means of physical culture and sports]. Candidate's thesis. 13.00.07, Drogobich, 2015, p. 227 [in Ukrainian].

5. Chepil M. M. Patriotychne vykhovannia v pedahohichnii kontseptsii Hryhoriia Vashchenka. [Patriotic education in the pedagogical concept of Hryhoriy Vashchenko]. Pedahohichna osvita: teoriia i praktyka. Pedagogical education: theory and practice, 2015, issue 18, p. 116-121. Retrieved from Pedagogical education: theory and practice [in Ukrainian].

6. Cherepovska N. I. Mediaosvitni resursy rozvytku patriotyzmu i krytychnoho myslennia molodi : navchalno-metodychnyi posibnyk. [Media educational resources for the development of patriotism and critical thinking of young people : a textbook]. Natsionalna akademiia pedahohichnykh nauk Ukrainy, Instytut sotsialnoi ta politychnoi psykholohii. National Academy of Pedagogical Sciences of Ukraine, Institute of Social and Political Psychology, 2017, p. 156. Kropyvnytskyi : Imeks-LTD [in Ukrainian]. 